\title{
PENGUKURAN KUALITAS WEBSITE PEMERINTAH DEPOK TERHADAP KEPUASAN PENGGUNA DENGAN METODE WEBQUAL 4.0
}

\author{
Khairunnisa ${ }^{1}$, Sri Wasiyanti ${ }^{2}$ \\ ${ }^{1}$ Program Studi Sistem Informasi \\ STMIK Nusa Mandiri \\ Jl. Margonda Raya No. 8 Depok \\ xxiccaxx@gmail.com \\ ${ }^{2}$ Program Studi Komputerisasi Akuntansi \\ AMIK BSI Bandung \\ JI. Sekolah Internasional No. 1-6, Antapani Bandung \\ sri.siw@bsi.ac.id
}

\begin{abstract}
ABSTRAK
Pemanfaatan teknologi komunikasi dan informasi dalam proses pemerintahan akan meningkatkan efisiensi, efektifitas, transparansi dan akuntabilitas penyelenggaraan pemerintahan, telah disadari oleh negara Indonesia melalui Inpres No. 3 Th 2003, pemerintah dalam hal ini Departemen Komunikasi dan Informatika telah menetapkan Kebijakan dan Strategi Nasional tentang pengembangan e-government. Sehingga dituntut adanya website pemerintah yang berkualitas. Berdasarkan hal itu, penelitian ini mencoba untuk mengukur kualitas website pemerintah kota Depok yaitu www.depok.go.id yang ditinjau dari sisi kepuasan pengguna akhir menggunakan metode webqual 4.0, yang terdiri dari tiga dimensi yaitu usability (kemudahan penggunaan), information quality (kualitas informasi) dan interaction quality (kualitas interaksi). Pengambilan sampelnya adalah pegawai yang ada di Dinas Komunikasi dan Informatika (diskominfo) kota Depok karena dianggap dapat mewakili keseluruhan pegawai yang ada di kantor pemerintahan kota Depok dan sering mengakses website tersebut. Penelitian ini mendapatkan sebuah kesimpulan bahwa dari 3 dimensi webqual 4.0 hanya dimensi information quality dan interaction quality yang dinilai berpengaruh terhadap kepuasan pengguna website, sedangkan dimensi usability dinilai tidak berpengaruh terhadap kepuasan pengguna website.
\end{abstract}

Kata Kunci : e-government, Kualitas Website, Webqual 4.0

\begin{abstract}
The utilization of information and communication technology in the governmental process will improve the efficiency, effectiveness, transparency and accountability of the government administration, has been recognized by the state of Indonesia through Presidential Decree No. 3 Th 2003, the government in this case the Ministry of Communications and Information Technology has set a National Policy and Strategy of the development of e-government. So this required quality government website. Accordingly, this study attempts to measure the quality of Depok city government website that www.depok.go.id viewed from the side of end user satisfaction using WebQual 4.0, which consists of three dimensions, namely usability (ease of use), information quality (quality information), and interaction quality (quality of interaction). The sample collection is an employee in the Office of Communications and Information Technology (diskominfo) Depok city as a whole is considered to represent an employee in Depok city government offices and often access the website. This research get a conclusion that from 3 dimension of webqual 4.0 only dimension of information quality and interaction quality which assessed have an effect on to website user's satisfaction, while usability dimension is not influenced to website user's satisfaction.
\end{abstract}

Keyword : e-government, Website Quality, Webqual 4.0 


\section{Pendahuluan}

Penerapan teknologi komunikasi dan informasi dalam pemerintahan, yang dikenal dengan sebutan e-government, diyakini akan memberikan keuntungan yang luas, tidak saja bagi negara dan para penyelenggaranya, tetapi juga bagi publik yang menerima layanan. Bahwasanya pemanfaatan teknologi komunikasi dan informasi dalam proses pemerintahan akan meningkatkan efisiensi, efektifitas, transparansi dan akuntabilitas penyelenggaraan pemerintahan, telah disadari oleh negara Indonesia. Melalui Inpres No. 3 Th 2003, pemerintah dalam hal ini Departemen Komunikasi dan Informatika telah menetapkan Kebijakan dan Strategi Nasional tentang pengembangan e-government. Selain itu peran sebuah website dalam pemerintahan Penelitian yang telah dilakukan dapat ditemukan bahwa dari 3 dimensi WebQual 4.0, hanya dimensi kegunaan dan kualitas interaksi yang dinilai berpengaruh kepada kepuasan pengguna, sedangkan dimensi kualitas informasi dinilai tidak berpengaruh tehadap kepuasan pengguna website (Sanjaya, 2012). Sedangkan Menurut (Wibowo, 2015), mengemukakan bahwa model analisis regresi atau model persamaan struktural dapat digunakan untuk menyelesaikan permasalahan yang melibatkan lebih dari dua variable (multivariat). Dalam penelitian ini digunakan analisis regresi berganda. Penelitian ini bertujuan untuk memeriksa hubungan antara variabel dependen (kepuasan pengguna) dan variabel independent (masing - masing dimensi dari webqual versi 4.0) .

Berdasarkan hal tersebut, penelitian ini mencoba untuk mengukur kualitas website pemerintah kota Depok yaitu www.depok.go.id yang ditinjau dari sisi kepuasan pengguna akhir menggunakan metode webqual 4.0, apakah telah sesuai dengan harapan pengguna khususnya pegawai yang ada di lingkungan kantor pemerintahan kota Depok. Pengambilan sampelnya adalah pegawai yang ada di Dinas Komunikasi dan Informatika (diskominfo) kota Depok karena dianggap dapat mewakili keseluruhan pegawai yang ada di kantor pemerintahan dianggap sangatlah penting karena dengan media inilah masyarakat akan langsung bertatap muka dengan pemerintah melalui dunia maya tanpa terbatas oleh ruang dan waktu. Sehingga dituntut adanya website pemerintah yang berkualitas.

Pada dasarnya seseorang akan menggunakan layanan website untuk mencari informasi yang cepat dan mudah diperoleh dan pengguna akan merasa terpuaskan jika layanan website yang dibuka tersebut sesuai dengan persepsi tentang mutu layanan informasi yang saat ini dirasakan dan tingkat harapan masa datang. Pemanfaatan dan kegunaan website dilihat dari seberapa baik fungsi dan seberapa efektif pengguna dapat bernavigasi merupakan salah satu faktor kunci kualitas layanan website (Susanto, 2013).

kota Depok dan sering mengakses website tersebut. Dalam penelitian ini memiliki perumusan hipotesis sebagai berikut:

$\mathrm{H} 1$ : Adanya pengaruh yang signifikan antara usability (kemudahan penggunaan) terhadap kepuasan pengguna website

H2: Adanya pengaruh yang signifikan antara information quality (kualitas informasi) terhadap kepuasan pengguna website

H3: Adanya pengaruh yang signifikan antara interaction quality (kualitas interaksi) terhadap kepuasan pengguna website

\section{Metode Penelitian}

Untuk mendapatkan data sebagai acuan dalam penulisan. Dalam penelitian ini digunakan beberapa metode untuk pengumpulan data:

\section{a. Observasi}

Dalam penyusunan penelitian ini penulis melakukan pengamatan secara langsung dengan mengunjungi kantor diskominfo Depok untuk mendapatkan data - data yang dibutuhkan terkait penelitian.

b. Wawancara

Melakukan wawancara terhadap pegawai diskominfo Depok untuk meminta persepsi mereka terhadap website pemkot Depok yaitu www.depok.go.id dengan memberikan 
sebuah kuesioner sebagai penilaian

c. Studi Pustaka

Dalam penyusunan laporan ini penulis mencari informasi melalui buku referensi atas kualitas website tersebut.

dan jurnal - jurnal penelitian terdahulu tentang analisis kualitas sebuah website terhadap kepuasan pengguna.

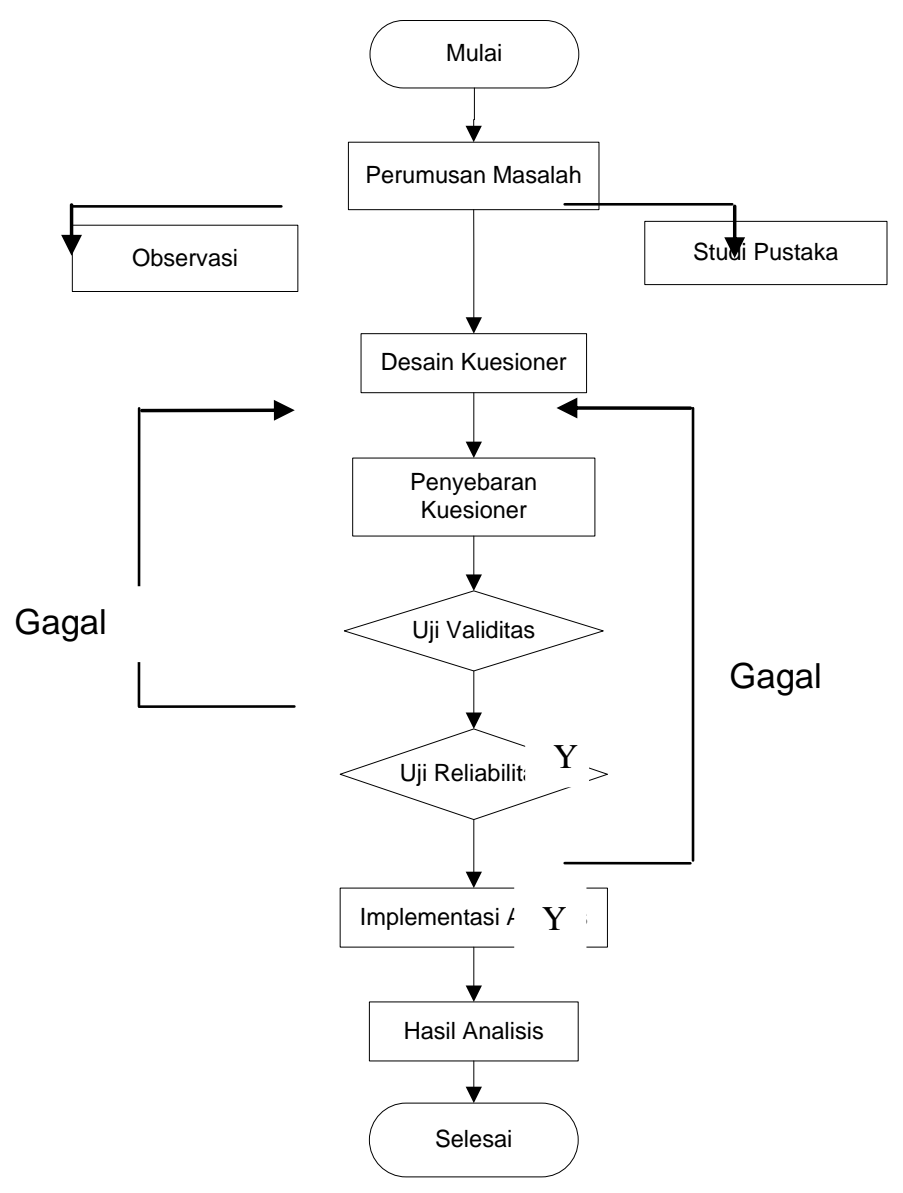

Sumber : Khairunissa dan Wasiyanti(2016)

\section{Gambar 1. Tahapan Penelitian}

Dalam tahapan penelitian seperti pada gambar 1 diatas, menunjukan jika proses validitas dan reliabilitas gagal maka kuesioner di desain ulang dengan mengikuti aturan webqual 4.0 yang menggunakan 3 dimensi utama yaitu kemudahan penggunaan (usability), kualitas informasi (information quality) dan kualitas interaksi (interaction quality).

Ketiga dimensi Webqual tersebut dijadikan variabel independent, sedangkan kepuasan pengguna dijadikan sebagai variabel dependen. Skala pengukuran yang digunakan dalam penelitian ini adalah 4 poin skala Likert. Pengguna akan diminta menilai website untuk kualitas masingmasing menggunakan skala mulai dari 1 (sangat tidak setuju) hingga 4 (sangat setuju). Skala sengaja dibuat genap untuk menghindari kecenderungan responden yang besikap netral. Sampel yang diambil sebanyak 32 responden.

Ukuran sampel ini sesuai dengan penelitian yang dilakukan oleh Barnes dan Vidgen (2001) dalam mengukur kualitas website berita. Sampel dipilih secara purposive sampling karena responden harus memiliki kriteria pernah menggunakan website www.depok.go.id. 
Pengujian hipotesis pada penelitian ini menggunakan regresi linier berganda karena variable independent lebih dari satu variable, yaitu kemudahan penggunaan

Keterangan :

$a$ : konstanta, $b$ : koefisien regresi

$\mathrm{X} 1$ : kemudahan penggunaan (usability)

$\mathrm{X} 2$ : kualitas informasi (information quality)

X3 : kualitas interaksi (interaction quality)

$\mathrm{Y}$ : kepuasan pengguna

\section{Hasil dan Pembahasan}

\subsection{Pengujian Validitas}

Langkah awal yang dilakukan adalah dengan melakukan uji validitas dan
(X1), kualitas informasi (X2) dan kualitas interaksi (X3). Adapun persamaan regresi linier bergandanya adalah

$$
\mathrm{Y}=\mathrm{a}+\mathrm{b} 1 \mathrm{X} 1+\mathrm{b} 2 \mathrm{X} 2+\mathrm{b} 2 \mathrm{X} 3
$$

reliabilitas dari pertanyaan - pertanyaan dalam kuesioner. Pada penelitian ini, teknik uji validitas yang digunakan adalah teknik Corrected Item Total Correlation. Pengujian signifikasi dilakukan dengan kriteria menggunakan $r$ tabel pada tingkat signifikansi 0,05 dengan uji 2 sisi. Jika nilai positif dan $r$ hitung $>r$ tabel, maka item dapat dinyatakan valid, jika $r$ hitung $<r$ tabel maka item dinyatakan tidak valid".

Tabel 1. Hasil Perhitungan Pengujian Validitas

\begin{tabular}{|c|c|c|c|}
\hline No & $\mathbf{r}$ hitung & $\mathbf{r}$ tabel & Keterangan \\
\hline 1 & .778 & 0.361 & Valid \\
\hline 2 & .602 & 0.361 & Valid \\
\hline 3 & .831 & 0.361 & Valid \\
\hline 4 & .768 & 0.361 & Valid \\
\hline 5 & .903 & 0.361 & Valid \\
\hline 6 & .888 & 0.361 & Valid \\
\hline 7 & .818 & 0.361 & Valid \\
\hline 8 & .903 & 0.361 & Valid \\
\hline 9 & .565 & 0.361 & Valid \\
\hline 10 & .900 & 0.361 & Valid \\
\hline 11 & .792 & 0.361 & Valid \\
\hline 12 & .958 & 0.361 & Valid \\
\hline 13 & .808 & 0.361 & Valid \\
\hline 14 & .803 & 0.361 & Valid \\
\hline 15 & .900 & 0.361 & Valid \\
\hline 16 & .602 & 0.361 & Valid \\
\hline 17 & .831 & 0.361 & Valid \\
\hline 18 & .792 & 0.361 & Valid \\
\hline 19 & .958 & 0.361 & Valid \\
\hline 20 & .565 & 0.361 & Valid \\
\hline 21 & .958 & 0.361 & Valid \\
\hline 22 & .831 & 0.361 & Valid \\
\hline 23 & .958 & 0.361 & Valid \\
\hline & & & \\
\hline
\end{tabular}




\subsection{Pengujian Reliabitias}

Berdasarkan table 1 diatas, dapat disimpulkan bahwa seluruh butir pernyataan memiliki nilai $r$ hitung (nilai pada Corrected Item Total Corelation) lebih besar dari nilai $r$ tabel (didapat dari tabel $r$ ). Tabel $r$ menggunakan signifikansi 0,05 dengan uji 2 sisi dan $\mathrm{N}$ (jumlah responden) $=32$

$\mathrm{Df}=\mathrm{N}-2$

$\mathrm{Df}=32-2$

$\mathrm{Df}=\quad 30 \rightarrow \mathrm{Df}=0.361$

maka didapat nilai $r$ tabel sebesar 0,361 . Jadi, seluruh variabel pernyataan yang ada pada kuesioner dapat dinyatakan valid.

Tabel 2. Hasil Perhitungan Pengujian Reliabilitas

\begin{tabular}{|l|l|}
\hline Cronbach's < & N of Items \\
\hline .977 & 23 \\
\hline
\end{tabular}

Berdasarkan hasil dari analisis reliabilitas dengan teknik Cronbach Alpha, dapat diketahui nilai Cronbach Alpha adalah 0,977. Menurut Sekaran dalam (Prayitno, 2014), "reliabilitas kurang dari 0,6 adalah kurang baik, sedangkan 0,7 dapat diterima dan diatas 0,8 adalah baik". Karena nilai $>0,6$ instrumen kuesioner dinyatakan reliabel.

\subsection{Pengujian Webqual 4.0}

Berikut ini adalah isi dari kuesioner berdasarkan dimensi dan aturan webqual 4.0 yang telah disesuaikan dengan tema penelitian

Tabel 3. Kuesioner Webqual 4.0

\begin{tabular}{|c|c|c|}
\hline No & $\begin{array}{c}\text { Nama } \\
\text { Variabel }\end{array}$ & Daftar Pernyataan \\
\hline \multicolumn{3}{|c|}{ Usability } \\
\hline 1 & $\mathrm{X} 11$ & $\begin{array}{l}\text { Saya merasa mudah untuk mempelajari } \\
\text { cara mengoperasikan website } \\
\text { www.depok.go.id/ }\end{array}$ \\
\hline 2 & $\mathrm{X} 12$ & $\begin{array}{l}\text { Saya merasa jelas dan paham } \\
\text { berinteraksi dengan website } \\
\text { www.depok.go.id/ }\end{array}$ \\
\hline 3 & $\mathrm{X} 13$ & $\begin{array}{l}\text { Saya merasa mudah menjalankan } \\
\text { menu dari website www.depok.go.id/ }\end{array}$ \\
\hline 4 & $\mathrm{X} 14$ & $\begin{array}{l}\text { Saya merasa mudah menggunakan } \\
\text { website www.depok.go.id/ }\end{array}$ \\
\hline 5 & $\mathrm{X} 15$ & $\begin{array}{l}\text { Website www.depok.go.id/ memiliki } \\
\text { tampilan yang menarik }\end{array}$ \\
\hline 6 & $\mathrm{X} 16$ & $\begin{array}{l}\text { Desain website www.depok.go.id/ } \\
\text { sesuai dengan website kepemerintahan }\end{array}$ \\
\hline 7 & $\mathrm{X} 17$ & $\begin{array}{l}\text { Website www.depok.go.id/ memberikan } \\
\text { pengetahuan tentang informasi kota } \\
\text { Depok }\end{array}$ \\
\hline 8 & X18 & $\begin{array}{l}\text { Website www.depok.go.id/ memberikan } \\
\text { hal positif untuk saya }\end{array}$ \\
\hline \multicolumn{3}{|c|}{ Information Quality } \\
\hline 9 & $\mathrm{X} 21$ & $\begin{array}{l}\text { Website www.depok.go.id/ memberikan } \\
\text { informasi yang akurat }\end{array}$ \\
\hline 10 & $\mathrm{X} 22$ & $\begin{array}{l}\text { Website www.depok.go.id/ memberikan } \\
\text { informasi yang dapat dipercaya }\end{array}$ \\
\hline 11 & $\mathrm{X} 23$ & $\begin{array}{l}\text { Website www.depok.go.id/ memberikan } \\
\text { informasi dengan tepat waktu }\end{array}$ \\
\hline 12 & X24 & $\begin{array}{l}\text { Website www.depok.go.id/ memberikan } \\
\text { informasi yang berkaitan dengan badan } \\
\text { kepemerintahan dan informasi kota } \\
\text { Depok }\end{array}$ \\
\hline 13 & $\mathrm{X} 25$ & Website www.depok.go.id/ memberikan \\
\hline
\end{tabular}




\begin{tabular}{|c|c|c|}
\hline & & informasi yang mudah dipahami \\
\hline 14 & X26 & $\begin{array}{l}\text { Website www.depok.go.id/ memberikan } \\
\text { informasi yang tepat secara detail }\end{array}$ \\
\hline 15 & X27 & $\begin{array}{l}\text { Website www.depok.go.id/ memberikan } \\
\text { informasi dengan format sesuai dengan } \\
\text { badan pemerintahan }\end{array}$ \\
\hline \multicolumn{3}{|c|}{ Interaction Quality } \\
\hline 16 & X31 & $\begin{array}{l}\text { Website www.depok.go.id/ memiliki } \\
\text { reputasi yang baik }\end{array}$ \\
\hline 17 & X32 & $\begin{array}{l}\text { Saya merasa aman saat mengupload } \\
\text { dan mendownload di website } \\
\text { www.depok.go.id/ }\end{array}$ \\
\hline 18 & X33 & $\begin{array}{l}\text { Saya merasa aman saat input data } \\
\text { pribadi pada website www.depok.go.id/ }\end{array}$ \\
\hline 19 & X34 & $\begin{array}{l}\text { Website www.depok.go.id/ memberikan } \\
\text { kesan menarik minat dan perhatian }\end{array}$ \\
\hline 20 & X35 & $\begin{array}{l}\text { Website www.depok.go.id/ memberikan } \\
\text { rasa komunitas }\end{array}$ \\
\hline 21 & X36 & $\begin{array}{l}\text { Website www.depok.go.id/ memberikan } \\
\text { kemudahan dalam melakukan } \\
\text { komunikasi dengan pihak pemkot } \\
\text { Depok }\end{array}$ \\
\hline 22 & X37 & $\begin{array}{l}\text { Saya merasa yakin dengan informasi } \\
\text { yang diberikan website } \\
\text { www.depok.go.id/ }\end{array}$ \\
\hline \multicolumn{3}{|c|}{ Overall Impresion } \\
\hline 23 & $Y$ & $\begin{array}{l}\text { Saya merasa website ini secara } \\
\text { keseluruhan sudah baik }\end{array}$ \\
\hline
\end{tabular}

Hasil dari pengolahan kuesioner yang telah diisi oleh responden dapat dilihat pada table 4. berikut ini :

Tabel 4. Hasil Pengolahan Kuesioner

\begin{tabular}{|c|c|c|c|c|c|c|}
\hline Pernyataan & SS & S & TS & STS & Jumlah & Ratarata \\
\hline X11 & 0 & 25 & 7 & 0 & 89 & 2.78 \\
\hline X12 & 0 & 22 & 10 & 0 & 86 & 2.69 \\
\hline X13 & 0 & 29 & 3 & 0 & 93 & 2.91 \\
\hline X14 & 0 & 29 & 3 & 0 & 93 & 2.91 \\
\hline X15 & 0 & 29 & 3 & 0 & 93 & 2.91 \\
\hline X16 & 0 & 27 & 5 & 0 & 91 & 2.84 \\
\hline X17 & 0 & 30 & 2 & 0 & 94 & 2.94 \\
\hline X18 & 0 & 29 & 3 & 0 & 93 & 2.91 \\
\hline X21 & 0 & 24 & 8 & 0 & 88 & 2.75 \\
\hline X22 & 0 & 26 & 6 & 0 & 90 & 2.81 \\
\hline X23 & 0 & 25 & 7 & 0 & 89 & 2.78 \\
\hline X24 & 0 & 27 & 5 & 0 & 91 & 2.84 \\
\hline X25 & 0 & 24 & 8 & 0 & 88 & 2.75 \\
\hline X26 & 0 & 25 & 7 & 0 & 89 & 2.78 \\
\hline X27 & 0 & 26 & 6 & 0 & 90 & 2.81 \\
\hline X31 & 0 & 24 & 8 & 0 & 88 & 2.75 \\
\hline X32 & 0 & 18 & 11 & 3 & 79 & 2.47 \\
\hline X33 & 0 & 31 & 1 & 0 & 95 & 2.97 \\
\hline X34 & 0 & 23 & 9 & 0 & 87 & 2.72 \\
\hline
\end{tabular}




\begin{tabular}{|c|c|c|c|c|c|c|}
\hline $\mathrm{X} 35$ & 0 & 16 & 12 & 4 & 76 & 2.38 \\
\hline $\mathrm{X} 36$ & 0 & 21 & 11 & 0 & 85 & 2.66 \\
\hline $\mathrm{X} 37$ & 0 & 18 & 14 & 0 & 82 & 2.56 \\
\hline $\mathrm{Y}$ & 0 & 27 & 5 & 0 & 91 & 2.84 \\
\hline
\end{tabular}

Keterangan :

Jumlah : Jumlah jawaban responden dikali angka pengukuran skala likert $\left(S S^{*} 4\right)+(S * 3)+\left(T S^{*} 2\right)+\left(S T S^{*} 1\right)$

Rata-rata : Jumlah dibagi jumlah responden (32 orang)

\subsection{Pengujian Hipotesis}

Untuk pengujian hipotesis, terdapat 3 (tiga) langkah yang harus dilakukan,dalam penelitian ini menggunakan metode regresi linier berganda. Pertama uji regresi parsial dengan $u j i ~ t$, kedua interprestasikan koefisien determinasi dan ketiga uji regresi simultan dengan uji $F$.

\section{a. Uji Signifikansi parsial (Uji Statistik t)}

Tabel 5. Hasil Uji t Pertama

\begin{tabular}{|l|l|l|l|l|l|}
\hline \multirow{2}{*}{ Model } & \multicolumn{2}{|l|}{$\begin{array}{l}\text { Unstandardized } \\
\text { Coefficients }\end{array}$} & $\begin{array}{l}\text { Standardized } \\
\text { Coefficients }\end{array}$ & \multicolumn{2}{|c|}{} \\
\cline { 2 - 7 } & B & $\begin{array}{l}\text { Std. } \\
\text { Error }\end{array}$ & Beta & $\mathrm{t}$ & Sig. \\
\hline 1 (Constant) & -.165 & .167 & & -.985 & .333 \\
Usability & .101 & .186 & .091 & .543 & .592 \\
information quality & .362 & .171 & .349 & 2.115 & .043 \\
interaction quality & .614 & .294 & .540 & 2.090 & .046 \\
\hline
\end{tabular}

a. Dependent Variable: kepuasan pengguna

Berdasarkan tabel Coefficients diatas, dapat dilihat bahwa dari ketiga variabel independent hanya variabel X2 (information quality) dan X3 (interaction quality) yang signifikan pada $\alpha=5 \%$. Hal ini terlihat dari probabilitas signifikansi kedua variabel tersebut yang memiliki nilai dibawah 0,05.
Dengan demikian, variabel X1 (usability) dikeluarkan dari model karena tidak signifikan atau tidak memberikan pengaruh kepada variabel $Y$ (kepuasan pengguna). Oleh karena itu, dilakukan regresi ulang tanpa melibatkan konstanta dan variabel X1 (usability). Hasil analisis regresi dapat dilihat pada tabel 6 .

Tabel 6. Hasil Uji t Kedua

Coefficients $^{\mathrm{a}}$

\begin{tabular}{|c|c|c|c|c|c|}
\hline \multirow[b]{2}{*}{ Model } & \multicolumn{2}{|c|}{$\begin{array}{l}\text { Unstandardized } \\
\text { Coefficients }\end{array}$} & \multirow{2}{*}{$\begin{array}{c}\begin{array}{c}\text { Standardized } \\
\text { Coefficients }\end{array} \\
\text { Beta }\end{array}$} & \multirow[b]{2}{*}{$\mathrm{T}$} & \multirow[b]{2}{*}{ Sig. } \\
\hline & B & Std. Error & & & \\
\hline 1 (Constant) & -.157 & .165 & & -.951 & .349 \\
\hline $\begin{array}{l}\text { information } \\
\text { quality }\end{array}$ & .334 & .161 & .322 & 2.072 & .047 \\
\hline $\begin{array}{l}\text { interaction } \\
\text { quality }\end{array}$ & .740 & .177 & .651 & 4.192 & .000 \\
\hline
\end{tabular}

a. Dependent Variable: kepuasan pengguna 
Dengan demikian model regresi yang terbentuk adalah sebagai berikut :

$$
\mathrm{Y}=0,334 \mathrm{X} 2+0,740 \mathrm{X} 3
$$

Berdasarkan persamaan diatas dapat disimpulkan :

Jika variabel information quality (X2) berubah satu unit skor maka kepuasan pengguna $(\mathrm{Y})$ akan berubah sebesar 0,334 unit skor. Tanda positif menunjukan Jika variabel interaction quality (X3) berubah satu unit skor maka kepuasan pengguna $(\mathrm{Y})$ akan berubah sebesar 0,740 unit skor. Tanda positif menunjukan perubahan yang searah. Apabila perubahan yang searah. Apabila information quality meningkat maka kepuasan pengguna juga meningkat. Dan sebaliknya, jika information quality menurun, maka kepuasan pengguna juga menurun.

interaction quality meningkat maka kepuasan pengguna juga meningkat. Dan sebaliknya, jika interaction quality menurun, maka kepuasan pengguna juga menurun.

\section{b. Koefisien Determinasi}

Tabel 7. Hasil Koefisien Determinasi Model Summary

\begin{tabular}{|l|c|c|r|r|}
\hline Model & $\mathrm{R}$ & $\begin{array}{c}\mathrm{R} \\
\text { Squar } \\
\mathrm{e}\end{array}$ & $\begin{array}{c}\text { Adjusted } \\
\text { R Square }\end{array}$ & $\begin{array}{c}\text { Std. Error } \\
\text { of the } \\
\text { Estimate }\end{array}$ \\
\hline 1 & $.961^{\mathrm{a}}$ & .924 & .919 & .10527 \\
\hline
\end{tabular}

a. Predictors: (Constant), interaction

quality, information quality

Tampilan output SPSS model summary menunjukan besarnya $R^{2}$ sebesar 0,924 . Artinya variabel independent $\mathrm{X} 2$ (information quality) dan X3 (interaction quality) dapat menerangkan variabilitas sebesar $92,4 \%$ dari variabel dependen $\mathrm{Y}$ (kepuasan pengguna). Sedangkan sisanya $(100 \%-92,4 \%=7,6 \%)$ dijelaskan oleh faktor lain diluar dimensi webqual 4.0 .

\section{c. Uji Signifikansi simultan (Uji Statistik F)}

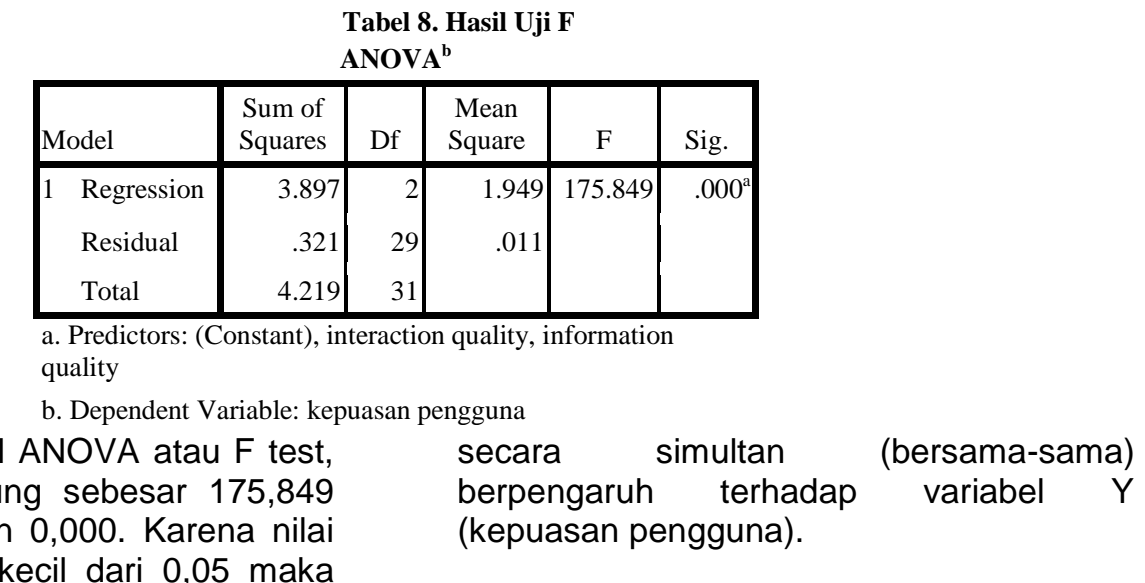
signifikan jauh lebih kecil dari 0,05 maka dapat disimpulkan bahwa model secara keseluruhan dapat dianggap baik dan variabel independent $\mathrm{X} 2$ dan $\mathrm{X} 3$ tersebut 
3.5. Hasil Pengujian Hipotesis

$\begin{array}{lr}\text { Dimensi usability } & \text { (kemudahan } \\ \text { penggunaan) terhadap } & \text { kepuasan } \\ \text { pengguna website : } & \end{array}$

Hasil uji $t$ yang diambil berdasarkan nilai koefisien B untuk X1 (usability) sebesar 0,101 dengan tingkat signifikan sebesar 0,592 maka tidak signifikan pada $\alpha=5 \%$ atau $(p>0,05)$.

Maka $\mathrm{H} 1$ ditolak atau hal ini menunjukan bahwa tidak adanya pengaruh yang signifikan antara usability (kemudahan penggunaan) terhadap kepuasan pengguna website.

Dimensi information quality (kualitas informasi) terhadap kepuasan pengguna website :

Hasil uji $t$ yang diambil berdasarkan nilai koefisien B untuk X2 (information quality) sebesar 0,334 dengan tingkat signifikan sebesar 0,047 maka signifikan pada $\alpha=5 \%$ atau $(\mathrm{p}<0,05)$.

Maka H2 diterima atau hal ini menunjukan bahwa adanya pengaruh yang signifikan antara information quality (kualitas informasi) terhadap kepuasan pengguna website.

Dimensi interaction quality (kualitas interaksi) terhadap kepuasan pengguna website:

Hasil uji t yang diambil berdasarkan nilai koefisien B untuk X3 (interaction quality) sebesar 0,740 dengan tingkat signifikan sebesar 0,000 maka signifikan pada $\alpha=5 \%$ atau $(p<0,05)$.

Maka H3 diterima atau hal ini menunjukan bahwa adanya pengaruh yang signifikan antara interaction quality (kualitas interaksi) terhadap kepuasan pengguna website.

\section{Kesimpulan}

Dari 3 dimensi webqual 4.0 hanya dimensi information quality dan interaction quality yang dinilai berpengaruh terhadap kepuasan pengguna website, sedangkan dimensi usability dinilai tidak berpengaruh terhadap kepuasan pengguna website. Tidak berpengaruhnya dimensi usability bisa diinterpretasikan sebagai rendahnya kemudahan dalam penggunaan website yang diberikan oleh website pemerintah kota Depok yaitu www.depok.go.id. Hal ini bisa disebabkan karena sebagian responden menganggap website pemkot Depok kurang jelas dan sulit dipahami dalam berinteraksi dengan pengguna serta masih sulitnya menjalankan menu yang ada di website dan sebagainya. Berdasarkan hasil uji $f$ dan tingkat signifikan variabel $X 2$ dan $X 3$ yaitu information quality dan interaction quality yang diperoleh, menunjukan bahwa terdapat pengaruh yang positif dan signifikan terhadap kepuasan pengguna website pemkot Depok yaitu www.depok.go.id secara simultan (bersama - sama). Dimensi usability atau kemudahan penggunaan website dianggap tidak berpengaruh terhadap kepuasan pengguna, hal ini mungkin dikarenakan responden di kantor diskominfo Depok lebih banyak yang berusia 36 - 45 tahun yaitu sebanyak 21 orang. Maka dari itu, kebanyakan responden adalah orang yang memiliki usia yang tergolong tua yang tidak terbiasa dengan penggunaan sebuah website sehingga responden merasa sulit dengan penggunaan website tersebut. Selain itu, tidak semua orang mampu untuk mengoperasikan sebuah website dan paham dengan tampilan website.

\section{Referensi}

Prayitno, D. (2014). SPSS 22 Pengolah

Data Terpraktis . Yogyakarta: Andi.

Sanjaya, I. (2012). Pengukuran Kualitas layanan Website kementrian Kominfo dengan Menggunakan Metode Webqual 4.0 . IPTEK-KOM , 1-14.

Susanto, W. d. (2013). Evaluasi Kualitas layanan Website Pusdiklat BPK RI Menggunakan Metode Webqual Modifikasian dan Importance Performance Analysis. JNTETI , 7-14.

Wibowo, N. Q. (2015). Pengukuran Kualitas Layanan Sistem Informasi Akademik Menggunakan Metode Webqual 4.0. Jurnal Informatika UPGRIS , 112-119. 